\title{
Organization of Ribosomal RNA Genes from a Loofah Witches' Broom Phytoplasma
}

\author{
KUO-CHIEH HO, CHI-CHANG TSAI, and TE-LEI CHUNG
}

\begin{abstract}
Using the technique of integrative mapping with three vectors carrying chromosomal rDNA sequences, one of two rRNA operons of loofah witches' broom (LfWB) phytoplasma was constructed. This is the first complete rRNA operon of a phytoplasma to be reported. The operon has a context of $5^{\prime}-16 \mathrm{~S}-23 \mathrm{~S}-5 \mathrm{~S}-3^{\prime}$ with a tRNA $^{\text {Ile }}$ gene in the ITS and tRNA ${ }^{\mathrm{Val}}$ and tRNA ${ }^{\text {Asn }}$ genes downstream from the 5S rRNA gene. Although the other operon has not been cloned, the DNA sequence of a PCR-amplified product shows that it has no tRNA $^{\text {Ile }}$ gene in the ITS region. The complete nucleotide sequences of 16S, 23S, and $5 \mathrm{~S}$ rDNA are 1538, 2864, and $113 \mathrm{bp}$, respectively. Five - 10-like sequences, but no - 35 sequences, were found within a 494-bp leader region. There was a TG dinucleotide two nucleotides upstream from each -10 -like sequence. The existence of a TG dinucleotide at this position has been reported to enhance the efficiency of a promoter without a -35 region. The regions immediately flanking the $5^{\prime}$ and $3^{\prime}$ ends of $16 S$ and $23 S$ rDNA can form long basepaired stems that contain sites for processing by RNase III. No obvious sequence for a rho-dependent or rho-independent termination site was found downstream from the tRNA ${ }^{\text {Asn }}$ gene. The transcription may stop within a pyrimidine-rich region, as has been reported for several polypeptide-encoding genes and rRNA operons of archaeobacteria. The presence of the tRNA genes downstream from the 5S rRNA gene in the rRNA operon of LfWB phytoplasma further supports the hypothesis that phytoplasmas are phylogenetically closer to acholeplasmas than to mycoplasmas. The phylogenetic relatedness of LfWB phytoplasma to other phytoplasmas is discussed on the basis of the nucleotide sequence of rRNA genes and ITS.
\end{abstract}

\section{INTRODUCTION}

$\mathbf{P}$ hytoplasmas, also known as mycoplasma-like organisms (MLOs), are a group of bacterial pathogens that are wallless and obligate parasites in the phloem of plants. They have small genomes, ranging from 500 to $1700 \mathrm{kbp}$, and a relatively low $\mathrm{G}+\mathrm{C}$ content (Razin, 1985). Inability to culture these organisms in vitro makes studies of their biologic and biochemical properties quite difficult, resulting in uncertainty about their taxonomy. Although they are classified as members of Class Mollicutes (Sears and Kirkpatrick, 1994), a genus cannot be assigned to them because of the lack of enough information (Tully, 1993).

Recently, molecular genetic analyses have increasingly been employed to identify and differentiate phytoplasmas. Because rRNAs are abundant and their sequences are conserved, the nucleotide sequences of rRNA genes and their PCR DNA prod- ucts are often used to define these organisms' taxonomy and phylogeny (Lim and Sears, 1989; Kirkpatrick et al., 1992; Kuske and Kirkpatrick, 1992; Gundersen et al., 1994; Razin et al., 1998). The organization of rRNA genes within an operon has been demonstrated to provide additional genetic evidence for the coherence of grouping (Ree et al., 1989; Menke et al., 1991). Escherichia coli and Bacillus subtilis contain, respectively, 7 and 10 copies of rRNA operons (rrns) in the genome, with a gene order of 5'-16S-23S-5S-3' (Lindahl and Zengel, 1986; Jinks-Robertson and Nomura, 1987; Srivastava and Schlessinger, 1990; Itaya, 1993). Although this gene order is common, it is not universal. There are three rrns in Thermus thermophilus with the order of $5^{\prime}-16 \mathrm{~S}-3^{\prime}, 5^{\prime}-23 \mathrm{~S}-5 \mathrm{~S}-3^{\prime}$, and 5'-23S-5S-3' (Srivastava and Schlessinger, 1990). Most mollicutes have two copies of rrns with the same gene order as $E$. coli (Bove, 1993). However, Mycoplasma hyopneumoniae has only one copy of $r r n$, and the $5 \mathrm{~S}$ is located far away from the 
16S-23S (Taschke et al., 1986). The rRNA genes in M. gallisepticum are separated into three transcription units with the gene order of $5^{\prime}-16 \mathrm{~S}-23 \mathrm{~S}-5 \mathrm{~S}-3^{\prime}, 5^{\prime}-23 \mathrm{~S}-5 \mathrm{~S}-3^{\prime}$, and $5^{\prime}-16 \mathrm{~S}-3^{\prime}$ (Chen and Finch, 1989). Schneider and Seemuller (1994) analyzed 28 phytoplasmas and found that they all contained two copies of rrns. However, the Western X-disease phytoplasma has only one copy (Kirkpatrick et al., 1987).

Another feature of the rrns is the presence of tRNA genes in the internal transcribed spacer (ITS) between the 16S and $23 \mathrm{~S}$ rRNA genes. In this region, all of the seven rrns in $E$. coli carry two tRNA genes, whereas only one of the $10 \mathrm{rrns}$ in $B$. subtilis carries two tRNA genes (Ogasawara et al., 1983; Gurtler and Barrie, 1995). No tRNA genes are found in this region of mollicutes with the exception of Acholeplasma laidlawai and phytoplasmas (Razin et al., 1998). The ITS in one of two A. laidlawii rrns contains two tRNA genes (Nakagawa et al., 1992). Twenty-six phytoplasmas analyzed by Smart et al. (1996) carried one tRNA gene in the ITS.

To further understand the evolution and structure of the phytoplasma genome, we have isolated and characterized several genes from a loofah witches' broom (LfWB) phytoplasma. This paper describes the cloning, mapping, and molecular characterization of an $r r n$. This is the first complete $r r n$ to be reported for a phytoplasma. Characterization of the rrns in LfWB phytoplasma should help us to elucidate the regulation of phytoplasma rRNA transcription and provide a close insight into the organisms' phylogeny.

\section{MATERIALS AND METHODS}

\section{Bacteria and plant}

The LfWB phytoplasmas were maintained by graft inoculation in periwinkles (Chen and Ho, 1997). The original diseased plant was provided by Dr. H.-J. Su, Professor of Department of Plant Pathology, National Taiwan University, Taiwan.

\section{Plant and phytoplasma DNA isolation}

DNA from healthy or LfWB phytoplasma-infected periwinkle was isolated using the procedure described by Ko and Lin (1994) and Kollar et al. (1990) with minor modifications. The plant branches $(15 \mathrm{~g})$ were disinfected with $1 \%$ sodium hyperchloric acid, rinsed with distilled water, and then briefly dried with tissue paper. Liquid nitrogen was added to a cooled mortar containing plant tissues, and the tissues were ground by a pestle and then by a coffee grinder. The powder was suspended in $15 \mathrm{ml}$ of extraction buffer $(500 \mathrm{mM} \mathrm{NaCl}, 100 \mathrm{mM}$ Tris $\mathrm{HCl}$, pH 8.0; 10 mM EDTA, $1 \%$ N-lauroyl sarcosine) and incubated at $55^{\circ} \mathrm{C}$ for $2 \mathrm{~h}$. After centrifugation at $10,000 \times g$, at $4^{\circ} \mathrm{C}$ for $20 \mathrm{~min}$, the supernatant liquid was mixed with $0.6 \mathrm{vol}$ of isopropanol. The mixture was chilled at $-20^{\circ} \mathrm{C}$ for $30 \mathrm{~min}$, and the DNA was precipitated at $10,000 \times g$ at $4^{\circ} \mathrm{C}$ for $20 \mathrm{~min}$. The pellet was resuspended in $5 \mathrm{ml}$ of TE $(10 \mathrm{mM}$ Tris $\mathrm{HCl}, 1 \mathrm{mM}$ EDTA, pH 8.0) containing $0.5 \%$ SDS and $500 \mu \mathrm{g}$ of proteinase K. After incubation at $37^{\circ} \mathrm{C}$ for at least $1 \mathrm{~h}, 875 \mu \mathrm{l}$ of $5 \mathrm{M} \mathrm{NaCl}$ and $700 \mu \mathrm{l}$ of $\mathrm{CTAB} / \mathrm{NaCl}$ solution $(10 \% \mathrm{CTAB}, 0.7 \mathrm{M} \mathrm{NaCl})$ were added. The incubation was continued for another $10 \mathrm{~min}$ at $65^{\circ} \mathrm{C}$. The mixture was extracted with chloroform-isoamyl alcohol (24:1) three times and then with phenol-chloroformisoamyl alcohol $(25: 24: 1)$ twice. The supernatant liquid was mixed with $0.6 \mathrm{vol}$ of isopropanol and chilled at $-20^{\circ} \mathrm{C}$ for $1 \mathrm{~h}$. DNA was precipitated at $12,000 \times g$ at $4^{\circ} \mathrm{C}$ for $20 \mathrm{~min}$. The pellet was rinsed with $75 \%$ alcohol, air dried, and then resuspended in $1 \mathrm{ml}$ of TE.

A CsCl-bisbenzimide density gradient was used to separate phytoplasma DNA from host plant DNA, as described by Harrison et al. (1991). The gradient was prepared as follows. The DNA solution (in TE), $\mathrm{CsCl}(\mathrm{g})$, and bisbenzimide $(0.5 \mathrm{mg} / \mathrm{ml}$ in TE) were combined at a ratio of 9.5:10.5:1. After centrifugation at 55,000 rpm in a p65VT3 rotor (Hitachi Koki Co., Ltd., Japan) at $20^{\circ} \mathrm{C}$ for $16 \mathrm{~h}$, the phytoplasma DNA was visualized under UV lights as the uppermost band in the gradient and was collected with a syringe. This DNA fraction was purified once more through the gradient and extracted three times with water-saturated butanol. After addition of three volumes of sterile distilled water and eight volumes of absolute alcohol and chilling at $-20^{\circ} \mathrm{C}$ for $1 \mathrm{~h}$, the DNA was precipitated. The DNA pellet was rinsed with $75 \%$ alcohol, dried, and dissolved in $500 \mu \mathrm{l}$ of TE.

\section{Phytoplasma genomic library construction and screening}

The LfWB phytoplasma DNA was partially digested with EcoRI or HindIII and cloned into $\lambda$ ZAP (ZAP Express System; Stratagene). Cell package extracts and in vitro packaging were prepared as previously described (Ho et al., 1992). The library contained $7.6 \times 10^{4}$ plaque-forming units ( $\mathrm{pfu}$ ) per milliliter with greater than $95 \%$ recombinants determined in the presence of isopropyl- $\beta$-D-thiogalactopyranoside (IPTG) and 5-bromo4-chloro-3-indolyl- $\beta$-D-galactoside (Xgal). The library was screened for the rRNA gene by plaque hybridization using a ${ }^{32} \mathrm{P}$-labeled rDNA fragment as the probe. The positive plaque areas were selected and rescreened until a single, isolated plaque could be picked up.

\section{Blot hybridization analysis}

Southern blot analysis was performed as previously described (Ho et al., 1992) at $42^{\circ} \mathrm{C}$ in the presence of $50 \%$ formamide and $0.1 \%$ SDS. The filter was washed in $0.1 \times \mathrm{SSC}$ $(1 \times \mathrm{SSC}: 15 \mathrm{mM} \mathrm{NaCl}, 15 \mathrm{mM}$ sodium citrate) containing $0.1 \% \mathrm{SDS}$ at $50^{\circ} \mathrm{C}$. The hybridized bands were detected by exposing the filter to a PhosphoImager screen (PhosphoImager 425; Molecular Dynamics).

\section{Polymerase chain reaction}

Two primers-ITS1: 5'AGTCGTAACAAGGTATC3' (nucleotides 1981 1997) and ITS2: 5'CTTAGTGCCAAGGCATC3' (nucleotides 2300 2284)-flanking the ITS were made to amplify the DNA fragment from LfWB phytoplasma DNA or cloned DNA template in a PCR. The first cycle of PCR was as follows: denaturation at $94^{\circ} \mathrm{C}$ for $5 \mathrm{~min}$, annealing at $45^{\circ} \mathrm{C}$ for $1 \mathrm{~min}$, and extension at $72^{\circ} \mathrm{C}$ for $1 \mathrm{~min}$. The reaction was continued for 35 cycles: denaturation at $94^{\circ} \mathrm{C}$ for $1 \mathrm{~min}$, annealing at $45^{\circ} \mathrm{C}$ for $1 \mathrm{~min}$, and extension at $72^{\circ} \mathrm{C}$ for $1 \mathrm{~min}$. Finally, the reaction was at $72^{\circ} \mathrm{C}$ for $5 \mathrm{~min}$. The products were subjected to gel electrophoretic analysis. 


\section{DNA sequence determination and analysis}

For DNA sequencing, the recombinant phage was converted into a phagemid by in vivo excision according to manufacturer's instructions (Stratagene). The sequence of the DNA insert in the recombinant phagemid was determined by a DNA automated sequencer (ABI Prism Model 377, v. 3.0; Applied Biosystems) using a step-by-step procedure in which synthetic primers for forward sequencing were designed from previously released sequences. DNA sequence analysis was performed using DNAStar software (DNASTAR).

\section{Accession Number}

The nucleotide sequence of the DNA fragment containing the LfWB phytoplasma rrn was deposited in GenBank with Accession Number AF251150.

\section{RESULTS}

\section{Cloning of rRNA operon}

Clone R4 containing a 1.6-kb insert DNA was obtained using the insert DNA from clone 138 as a probe to screen an $E c o$ RI genomic library of LfWB phytoplasma constructed in $\lambda$ ZAP vector. Clone 138 contained the rRNA genes of $M$. genitalium and was provided by Dr. P.-C. Hu (University of North Carolina at Chapel Hill, NC, USA). The 1.6-kb insert DNA contained a portion of $16 \mathrm{~S}$ rDNA, ITS, and one-third of the 23S rDNA. The second clone, H1, containing a 4.0-kb insert DNA, was obtained by screening a HindIII genomic library using the $1.6-\mathrm{kb}$ insert DNA of clone 4 as a probe. This insert DNA carried the complete 16S rDNA and its upstream portion, ITS, and two thirds of $23 \mathrm{~S}$ rDNA. In order to construct a complete LfWB phytoplasma $r r n$, a 3' $1.0-\mathrm{kb}$ EcoRI-HindIII fragment from the 4.0-kb insert DNA was used as a probe to screen the EcoRI genomic library. Thus, the third clone, R6, containing a $6.0-\mathrm{kb}$ insert DNA, was obtained. The insert DNA contained the other third of $23 \mathrm{~S}$ rDNA, the entire $5 \mathrm{~S}$ rDNA, two tRNA genes, and a stretch of sequence whose function was unknown. From a comparison of the nucleotide sequences of the $4.0-\mathrm{kb}$ and $6.0-\mathrm{kb}$ DNA fragments with the rrns of other mollicutes and gram-positive bacteria, the two fragments comprised a complete LfWB phytoplasma $r r n$ with a context of $5^{\prime}-16 \mathrm{~S}-23 \mathrm{~S}-5 \mathrm{~S}-3^{\prime}$, representing a typical rRNA gene organization of prokaryotes (Fig. 1).

\section{Copy number of rRNA operon in LfWB phytoplasma}

To find out the copy number of $r r n$ in LfWB phytoplasma, the genomic DNA digested with the restriction enzymes EcoRI, $E c o \mathrm{RV}$, HindIII, and $S c a \mathrm{I}$ was probed with the $1.6-\mathrm{kb}{ }^{32} \mathrm{P}-\mathrm{la}-$ beled EcoRI DNA fragment. As shown in Figure 2, there were two bands in the EcoRI-digested DNA, one band in the EcoRVdigested DNA, and two bands in the HindIII- and ScaI-digested DNAs. The probe DNA contained two adjacent $S c a$ I recognition sites and no EcoRV or HindIII recognition sites. The data indicate that there were two copies of $r r n s$ : one copy contained a HindIII recognition site within the fragment corresponding to the probe, and the other (shown in Fig. 1) did not. Figure 3A shows the results of the analysis of the PCR products amplified from LfWB phytoplasma DNA and recombinant plasmid

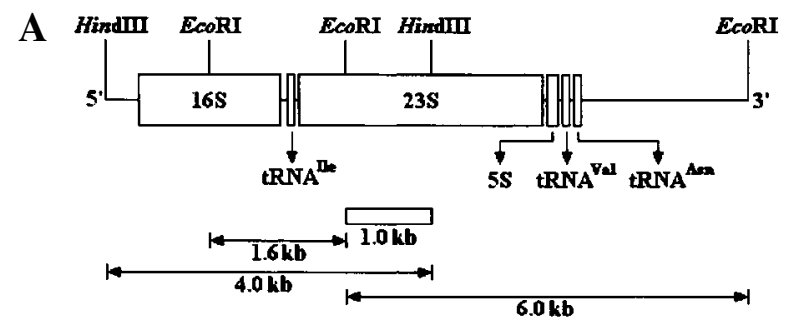

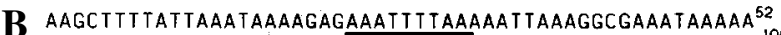
AAAAGGGTTT TAG T T TGATCCC[GTIAAAATITATATCTGT TCGTAAT T TAT TI 104 AAAAT TAGAGAT TTATTTAGCCAAAGGCAAAAAAAAATATGACAAAAGAGCC 156 GT TTTAAAAGAAAAAGATGACAAAATAAGAATTAAAAAAAGTTTAGAATAT T ${ }^{200}$

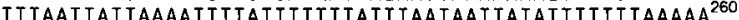

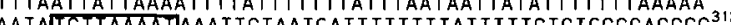
AATA GTAAAATAAATTGTAATCATTTTTTTTATTTTIGTGTCGGGAGGGG 364 TAGCGAAGTGGC TAAACGCATCAGICTGTAAAAC TGC ICCGIAAAGGTACGA ${ }^{364}$ TGG T TCGAATCCATCCCCCT TCACCAT TATATT TAT TIGAT TITITCTT TG AAAACT GAAGA IGATATIA G TAA T TAA IT T T T TATCAAAAAAACGAAT T T $T^{468}$

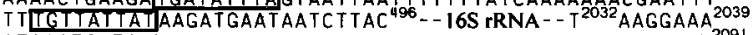
ATAAATCATCATC T TCAGT T TTGAAAGAC T TAGAT TAAATAAG T T T T TC T T T 2091

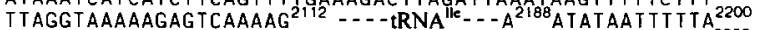
CI TAAAAAAAGT TC T T TGAAAAG TAGATAAACGTAAC T T TAAAAAT T CAAAT 2252 AA $2254-\cdots-23 S$ rRNA $-\cdots-T^{5117}$ TAATAAAGAATT TCT TAAAGT T TATG ${ }^{5143}$

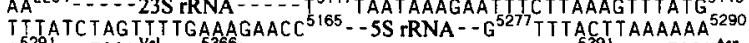

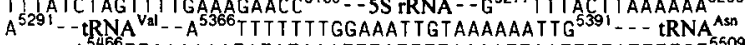

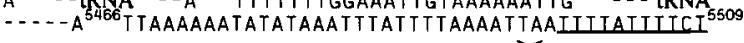
AAAG TGGIIUUAUUIIAAAAAATAATAACGATAAGGTAATACC T T TA

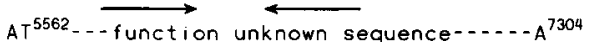

FIG. 1. Structure of rrn. (A) Restriction map of cloned $r r n$. The 1.6-kb, 4.0-kb, and 6.0-kb DNA fragments were inserted into clones R4, H1, and R6, respectively. The 1.0-kb EcoRIHindIII fragment used as probe to screen the library for clone R6 is indicated by an open bar. (B) Nucleotide sequence of DNA fragment containing $r r n$. Only $7304 \mathrm{bp}$ were determined. The coding regions of the 16S, 23S, and 5S rRNA genes, the tRNA genes, and most regions downstream from the tRNA ${ }^{\text {Asn }}$ gene are indicated by broken lines (not to scale). Five -10-like sequences and their immediate TG dinucleotides are boxed. The pyrimidine-rich sequences where the transcription possibly terminates are underlined. The inverted sequences are indicated by arrows.

DNA of clone R4 using primers flanking the ITS. There were two PCR products amplified from the LfWB phytoplasma DNA but only one product from the recombinant plasmid of clone $\mathrm{R} 4$. These data further support the presence of two $r$ rns in LfWB phytoplasma and indicate that the one that was not cloned had a short ITS. The data also explain the observation of two bands in EcoRI-digested DNA in Southern blotting. The DNA sequence analysis of the short ITS revealed a deletion of $53 \mathrm{nu}-$ cleotides in the $5^{\prime}$ region of the tRNA ${ }^{\text {Ile }}$ gene (Fig. 3B).

\section{Determination of the boundaries of the $16 S, 23 S$, and 5S rRNA genes}

The termini of the rRNA genes were determined by alignment of the nucleotide sequence or secondary structure with those of the respective rRNA gene of other microorganisms (Weisburg et al., 1989; Ludwig et al., 1992) (Fig. 4). The complete nucleotide sequence of the LfWB phytoplasma 16S rRNA gene was $1538 \mathrm{bp}$. Its $5^{\prime}$ and $3^{\prime}$ ends were located at $\mathrm{C}_{496}$ and $\mathrm{U}_{2032}$, respectively. The $23 \mathrm{~S}$ rRNA started at $\mathrm{A}_{2254}$ and ended at $\mathrm{U}_{5117}$ and had $2864 \mathrm{bp}$. The nucleotide sequences of $5 \mathrm{~S}$ rRNA are not conserved, as are those of $16 \mathrm{~S}$ and $23 \mathrm{~S}$ rRNA. In this report, the boundaries of $5 \mathrm{~S}$ rRNA were defined by comparing 


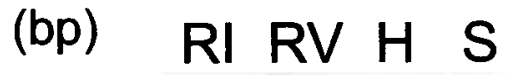

FIG. 2. Southern blot analysis of LfWB phytoplasma genomic DNA. The DNA digested with EcoRI (RI), EcoRV (RV), $\operatorname{HindIII}(\mathrm{H})$, and $S c a \mathrm{I}(\mathrm{S})$ was probed by a $1.6-\mathrm{kb}{ }^{32} \mathrm{P}$-labeled EcoRI fragment. The 2,645 and 1,605 are DNA size markers (pGEM DNA marker; Promega).

its sequence with those of $B$. subtilis and A. laidlawii, which are phylogenetically close to phytoplasmas (Ogasawara et al., 1983; Rogers et al., 1985). Our 5S rRNA began at $\mathrm{C}_{5165}$ and ended at $\mathrm{G}_{5277}$ and had $113 \mathrm{bp}$.

\section{Sequence analysis of the flanking and ITS regions of rRNA operon}

To search for the promoter and termination and processing signals, the regions flanking each rRNA gene were analyzed. Five possible -10 sequences, but no -35 sequences, were found within a 494-bp rrn leader region (see Fig. 1). The regions immediately flanking the $5^{\prime}$ and $3^{\prime}$ ends of the $16 \mathrm{~S}$ and 23S rDNA could form long basepaired stems that contained sites for processing by RNase III (Fig. 5). There was a tRNA ${ }^{\text {Ile }}$ gene in ITS and a tRNA ${ }^{\mathrm{Val}}$ gene as well as a tRNA ${ }^{\mathrm{Asn}}$ gene downstream from the 5S rRNA gene. No obvious sequence for a rho-dependent or rho-independent termination site was found downstream from the tRNA ${ }^{\text {Asn }}$ gene (see Fig. 1).

\section{DISCUSSION}

Currently, it is not possible to grow phytoplasmas in culture medium in vitro. In the absence of a proper cultivation method, characterization of cloned DNA fragments provides an impor- tant base for understanding the biochemical and physiological properties of these organisms in addition to delineating the structural organization of genes in the genome. The rRNA genes are particularly of interest because their products are essential to all cells, and their sequences are highly conserved. Although the 16S rRNA gene and ITS of phytoplasmas have been extensively investigated for the purpose of phylogenetic studies, no complete $23 \mathrm{~S}$ rRNA and $r r n$ have been reported.

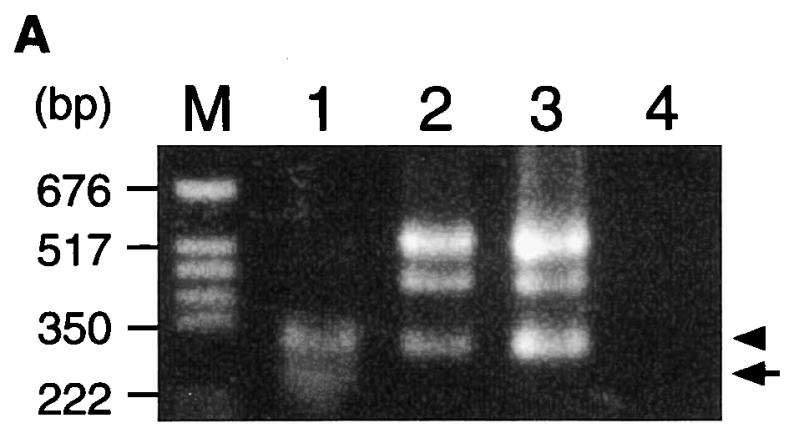

\section{B}

(1) AGTCGIAACA AGGIAICCCI ACCGGAAGGI GGGGATGGAI 40 AGTCGIAACA AGGTATCCCI ACCGGAAGGI GGGGATGGAI

CACCICCTIT CIAAGGAAAA TAAATCATCA TCTTCAGTTT 80 CACCICCITI CIAAGGAAAA TAAATCATCA TCTTCAGTTT

TGAAAGACTT AGATTAAATA AGTTTTTCTT TTTAGGTAAA 120 TGAAAGACTG AGATTAAATA AGTTTTTCTT TTTAGgTAAA

AAGAGTCAAA AGAGCCTATA GCTCAGTTGG ITAGAGCACA 160

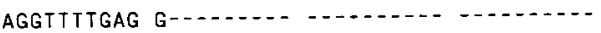

CGCCTGATAA GCGTGAGGTC GGTGGTTCAA GICCATTTAG 200

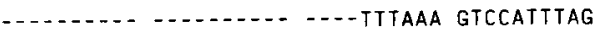

GCTCACCAAT ATAATTTTTA CTTAAAAAAA GTTCTTTGAA 240 GCTCACCAAT ATATTTTTTA CTTAAAAAAA GTTCTTTGAA

AAGTAGATAA ACGTAACTTT AAAAATTCAA ATAAAAAALT 280 AAGTAGATAA ACGTAACTTT AAAAATTCAA GTAAAAAAII

GAAGGAALIA AGGGCALACA GTGGATGCCT IGGCACTA 318 GAAGGAAIIA AGGGCATACA GIGGAIGCCI IGGCACTA

FIG. 3. Analysis of PCR products. (A) Gel electrophoretic analysis of products amplified from different DNA templates. Lane 1 = product from LfWB phytoplasma DNA; lane $2=$ product from recombinant plasmid of clone R4; lane 3 = product from recombinant plasmid of other clone containing the same insert DNA as clone R4; lane $4=$ PCR without a DNA template; lane $\mathrm{M}=$ DNA size markers (pGEM DNA marker; Promega). After electrophoresis, the agarose gel was stained with ethidium bromide. Arrowhead points to the DNA product containing ITS with a tRNA ${ }^{\text {Ile }}$ gene. Arrow points to the DNA product containing ITS without tRNA ${ }^{\text {Ile }}$ gene. (B) Nucleotide sequences of DNA products containing ITS. Line $1=$ the DNA product with tRNA ${ }^{\text {Ile }}$ gene; line $2=$ the DNA product without tRNA $^{\text {Ile }}$ gene. Dash represents the deleted nucleotides in $5^{\prime}$ region of tRNA ${ }^{\text {Ile }}$ gene. Underlined nucleotides are the flanking $16 \mathrm{~S}$ and $23 \mathrm{~S}$ rDNA sequences, respectively. 
A

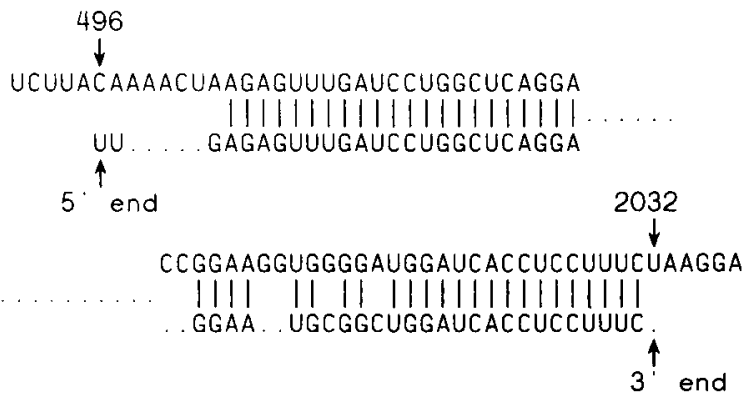

B

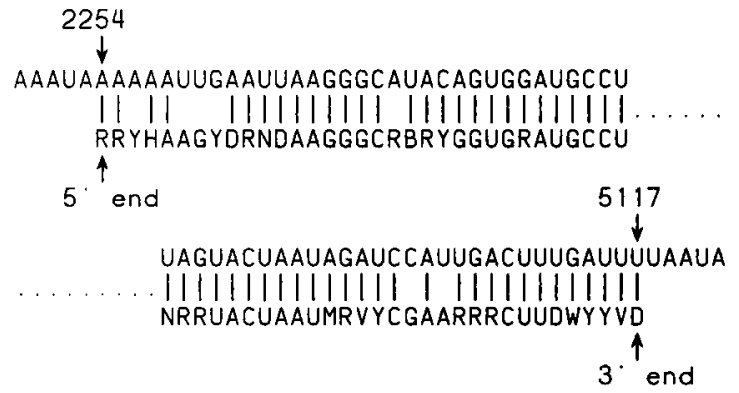

C

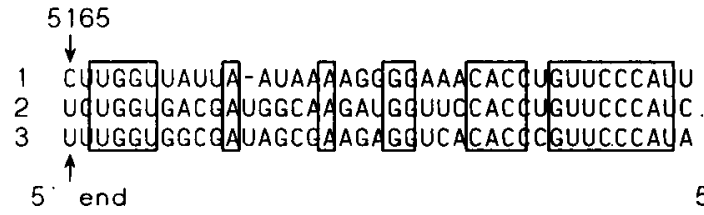

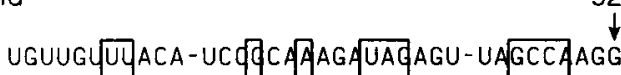
UA - - UULACAAUUA QCOAAAAUAGGACGUUGCCAGGC CGGGGQUUUCCCCCU GUGAGAQUAGGACGCDGCCAAGC

$3^{\circ}$ end

FIG. 4. Terminus determination of rRNA. The $5^{\prime}$ and $3^{\prime}$ portions of LfWB phytoplasma rRNAs were aligned with the corresponding regions of other bacterial rRNAs. (A) LfWB phytoplasma 16S rRNA (upper strand) with a 16S rRNA from a representative gram-positive bacterium (bottom strand). (B) LfWB phytoplasma 23S rRNA (upper strand) with a 23S rRNA from representative gram-positive bacterium (bottom strand). (C) The LfWB phytoplasma 5S rRNA (1) with 5S rRNAs of A. laidlawii (2) and B. Subtilis (3).

There are two copies of $r$ rns in phytoplasmas (Schneider and Seemuller, 1994) except the Western X-disease MLOs, which carry only one copy of $r r n$ (Kirkpatrick et al., 1987). In LfWB phytoplasma, our Southern blot and PCR analyses indicated that there were two copies of $r r n s$. The copy reported in this paper had a tRNA ${ }^{\text {Ile }}$ gene in the ITS and no HindIII recognition site in the 1.6-kb DNA fragment containing the ITS (see Fig. 1). The other copy had a HindIII recognition site and no tRNA ${ }^{\text {Ile }}$ gene in the $1.6-\mathrm{kb}$ DNA fragment. To our knowledge, this is the second report that a phytoplasma ITS contains no tRNA $A^{\text {Ile }}$ gene. The other one was that of StLL (Schneider et al., 1999).

Because LfWB phytoplasmas are obligate parasites of plants and their rRNA genes have high similarity to those of plant chloroplasts and mitochondria, it is difficult to purify phytoplasma rRNA for terminus analysis using primer extension and nuclease $\mathrm{S} 1$ mapping. The $5^{\prime}$ and $3^{\prime}$ termini of the rRNA genes were defined by comparison of the nucleotide sequences or secondary structures with those of other microorganisms. The same approach was used to define the boundaries of the 16S, 23S, and 5S rRNA genes of Rhodococcus facians (Pisabarro et al., 1998). The -10 promoter consensus sequence (TATAAT) found in prokaryotic rrns was consistently found in the promoter regions of the mollicutes (Rasmussen et al., 1987). However, it was not found in a 494-bp upstream region of LfWB phytoplasma16S rDNA. Instead, there were five -10-like sequences in this region (Fig. 1). Although no -35 (TTGACA/T) sequence was found upstream from the -10-like sequence, there was a TG dinucleotide two nucleotides upstream from each -10 -like sequence. Previous investigations have shown that the TG dinucleotide at this position is able to enhance the efficiency of a promoter without a -35 region (Keilty and Rosenberg, 1987; Ponnambalam et al., 1988). Mycoplasma hyopneumoniae is reported to have the same promoter characteristics (Taschke and Herrmann, 1986). It is possible that each of five -10 sequences in LfBW phytoplasma can promote initiation of rRNA transcription. Alternatively, the one nearest the 16S rDNA is the true -10 sequence, and the other four can be postulated to have a modulating effect on transcription by facilitating the binding of RNA polymerase and the formation of the initiation complex.

Because of the short distance between the 5S rRNA gene and its downstream tRNA ${ }^{\mathrm{Val}}$ gene, it was unlikely that a promoter sequence lay within this region. This implied that the tRNA $^{\mathrm{Val}}$ and tRNA ${ }^{\mathrm{Asn}}$ genes downstream from 5S rRNA were in the same transcription unit as the rRNA genes. No obvious sequence representing a typical rho-dependent or rho-independent termination site was found downstream from the tRNA ${ }^{\text {Asn }}$ gene. Transcription termination at indiscrete sites has been re-

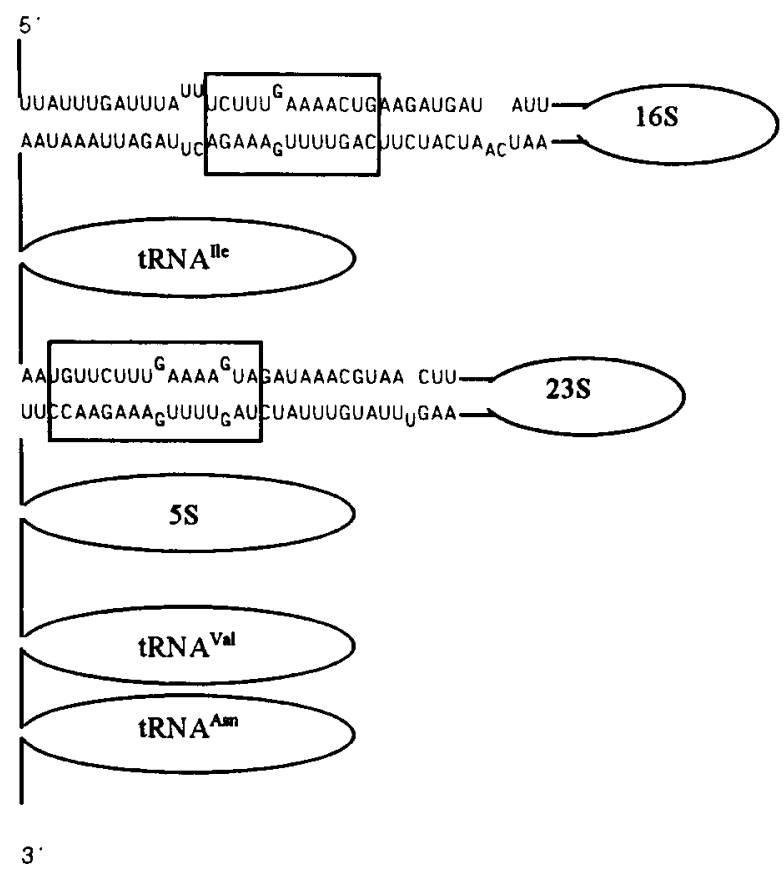

FIG.5. Schematic structure of $r r n$ and the putative stem structures surrounding the rRNA genes. The sites for processing by RNAse III are boxed. 


\section{LfWB phytoplasma}

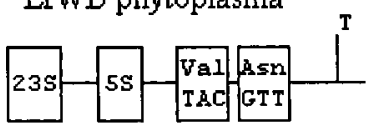

\section{Acholeplasma laidlawij}

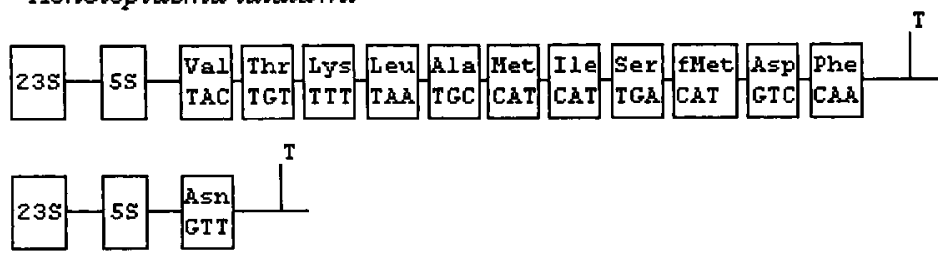

Bacillus stibtilis
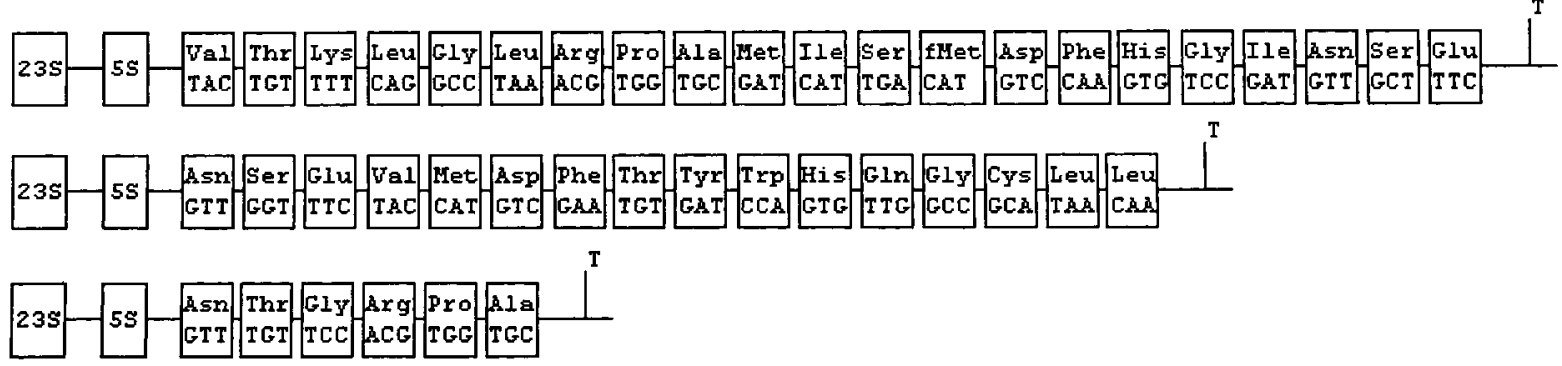

FIG. 6. The arrangement of tRNA genes downstream from the $5 \mathrm{~S}$ rRNA genes of LfWB phytoplasma, $A$. laidlawii, and $B$. subtilis. The tRNA genes are boxed. T represents the transcription terminator.

ported for several polypeptide-encoding genes and rrns of archaeobacteria, where transcription stops within or near a T-rich sequence (DasSarma et al., 1984; Hui and Dennis, 1985; Chant et al., 1986; Reiter et al., 1988; Brown et al., 1989). It was possible that the transcription of the LfWB phytoplasma $r r n$ terminated in one of several pyrimidine-rich regions immediately downstream from the tRNA ${ }^{\text {Asn }}$ gene (see Fig. 1). In M. genitalium, an Mgpar gene is located 100 bp downstream from the 5S rRNA gene (Fraser et al., 1995). However, no ORF was found within a 3.5-kb region downstream from the last tRNA ${ }^{\text {Asn }}$ gene in LfWB phytoplasma rrn.

Phytoplasmas are classified into 14 groups and 38 subgroups on the basis of restriction fragment length polymorphism analysis of PCR-amplified 16S rDNA sequences, and LfWB phytoplasma was assigned to 16SrVIII-A (Lee et al., 1998). Schneider et al. (1999) placed LfWB phytoplasma and StLL in the same cluster within the AshY group on the basis of 16S rRNA sequence homology. Using the ITS DNA sequences of LfWB phytoplasma and the sequences cited in the paper of Schneider et al. (1999) and Acholeplasma palmae (AF005323) as an outgroup, a phylogenetic tree was constructed by cluster analysis. The LfWB phytoplasma and StLL were in the same cluster; however, the cluster was not in the AshY group (data not shown). This might be attributable to the fact that the ITS sequences were more divergent. In addition to the DNA nucleotide sequence, the arrangement of the tRNA genes downstream from the 5S rRNA gene was used to infer that acholeplasmas evolved from gram-positive bacteria with low $\mathrm{G}+\mathrm{G}$ content (Tanaka et al., 1991). So far, no tRNA gene has been found downstream from the $5 \mathrm{~S}$ rRNA gene in mycoplasmas. There were two tRNA genes downstream from the $5 \mathrm{~S}$
rRNA gene in LfWB phytoplasma. In A. laidlawii, there were 11 and 1 tRNA gene(s) in the two rrns, respectively (Tanaka et al., 1991). In B. subtilis, 3 of the $10 \mathrm{rrns}$ contained several tRNA genes (Srivastava and Schlessinger, 1990). Data shown in Figure 6 suggest that two tRNA genes in LfWB phytoplasma might have been derived from the 21 tRNA genes of $B$. subtilis by a deletion during evolution, a process that might have similarly occurred in acholeplasmas. These data further support the view that phytoplasmas are phylogenetically closer to acholeplasmas than to mycoplasmas.

Also found in the rrn of LfWB phytoplasma were features similar to those of B. subtilis (Ogasawara et al., 1983), M. hyopneumoniae, and M. PG50 (Taschke and Herrmann, 1986; Rasmussen et al., 1987). The regions immediately flanking the $5^{\prime}$ and $3^{\prime}$ ends of the $16 \mathrm{~S}$ and $23 \mathrm{~S}$ rDNA could form long basepaired stems that contain sites for processing by RNase III. This suggests that LfWB phytoplasma might have the same rRNA maturation process as in the other three bacteria.

In conclusion, there are two copies of $r r n$ in the LfWB phytoplasma genome, one with and the other without a tRNA ${ }^{\text {Ile }}$ gene in the ITS. The copy presented in this paper was the one with a tRNA ${ }^{\text {Ile }}$ gene in the ITS and is the first complete phytoplasma $r r n$ to be reported. Our data should provide a base to elucidate the regulation of phytoplasmarRNA transcription and a close insight into phytoplasmas' phylogeny.

\section{ACKNOWLEDGMENTS}

We thank Drs. P.-C. Hu (University of North Carolina at Chapel Hill, NC, USA), H.-J. Su, and Y.-M. Chen for their 
long-term encouragement and support. We also thank Dr. TeChang Lee of the Institute of Biomedical Science, Academia Sinica, Taiwan, for providing aid in DNA autosequencing. This work was supported by Grants NSC 88-2311-B-002-032 and NSC 89-2311-B-002-010from the National Science Council of Taiwan to K.-C.H.

\section{REFERENCES}

BOVE, J.M. (1993). Molecular features of mollicutes. Clin. Infect. Dis. 17, 10-31.

BROWN, J.W., DANIELS, C.J., and REEVE, J.N. (1989). Gene structure, organization, and expression in archaeabacteria. CRC Crit. Rev. Microbiol. 16, 287-338.

CHANT, J., HUI, I., JONG-WONG, D.D., SHIMMIN, L., and DENNIS, P.P. (1986). The protein synthesizing machinery of the archaebacterium Halobacterium cutirubrum: Molecular characterization. Syst. Appl. Microbiol. 7, 106.

CHEN, X., and FINCH, L.R. (1989). Novel arrangement of rRNA genes in Mycoplasma gallisepticum: Separation of the $16 \mathrm{~S}$ gene of one set from the $23 \mathrm{~S}$ and $5 \mathrm{~S}$ genes. J. Bacteriol. 171, 2876-2878.

CHEN, L.-M., and HO, K.-C. (1997). Characterization of a phytoplasmarelated ribonuclease in Catharantus roseus. Taiwania 42, 8-16.

DASSARMA, S., RAJBHANDARY, U.L., and KHORANA, H.G. (1984). Bacterio-opsin mRNA in wild-type and bacterio-opsin-deficient Halobacterium halobium strains. Proc. Natl. Acad. Sci. USA 81, 125-129.

FRASER, C.M., GOCANE, J.D., WHITE, O., ADAMS, M.D., CLAYTON, R.A., FLEISCHMANN, R.D., BULT, C.J., KERLAVAGE, A.R., SUTTON, G., KELLEY, J.M., FRITCHMAN, J.L., WEIDMAN, J.F., SMALL, K.V., SANDUSKY, M., FUHRMANN, J., NGUYEN, D., UTTERBACK, T.R., SAUDEK, D.M., PHILLIPS, C.A., MERRICK, J.M., TOMB, J.-F., DOUGHERTY, B.A., BOTT, K.F., HU, P.-C., LUCIER, T.S., PETERSON, S.N., SMITH, H.O., HUTCHISON, III, C.A., and VERTER, J.C. (1995). The minimal gene complement of Mycoplasma genitalium. Science 270, 397-403.

GUNDERSEN, D.E., LEE, I.-M., REHNER, S.A., DAVIS, R.E., and KINGSBURY, T. (1994). Phylogeny of mycoplasma-like organisms (phytoplasmas): A basis for their classification. J. Bacteriol. 176, 5244-5254.

GURTLER, V., and BARRIE, H.D. (1995). Typing Staphylococcus aureus strains by PCR-amplification of variable-length 16S-23S rDNA spacer regions. Microbiology 141, 1255-1265.

HARRISON, N.A., BOURNE, C.M., COX, R.L., and RICHARDSON, P.A. (1991). Molecular cloning and deletion of chromosomal and extrachromosomal DNA of mycoplasma-like organisms associated witches' broom disease of pigeon pea in Florida. Mol. Plant-Microbe Interact. 4, 300-307.

HO, K.C., QUARMBY, V.E., FRENCH, F.S., and WILSON, E.M. (1992). Molecular cloning of rat prostate transglutaminase complementary DNA: The major androgen-regulated protein DP1 of rat dorsal prostate and coagulating gland. J. Biol. Chem. 267, 12660-12667.

HUI, I., and DENNIS, P.P. (1985). Characterization of the ribosomal RNA gene clusters in Halobacterium halobium. J. Biol. Chem. 260, 899.

ITAYA, M. (1993). Physical mapping of multiple homologous genes in the Bacillus subtilis 168 chromosome: Identification of ten ribosomal RNA operon loci. Biosci. Biotechnol. Biochem. 57, 16111614 .

JINKS-ROBERTSON, S., and NOMURA, M. (1987). Ribosomes and tRNA. In Escherichia coli and Salmonella typhimurium: Cellular and Molecular Biology. F.C. Neidhardt, J.L. Ingraham, K.B. Low, B. Magasanik, M. Schaechter, and H.E. Umbarger, eds. (American Society for Microbiology, Washington, D.C.) pp. 1358-1385.
KEILTY, S., and ROSENBERG, M. (1987). Constitutive function of a positively regulated promoter reveals new sequences essential for activity. J. Biol. Chem. 262, 6389-6395.

KIRKPATRICK, B.C., GAO, J., and HARRISON, N. (1992). Phylogenetic relationships of 15 MLOs established by PCR sequencing of variable regions within the $16 \mathrm{~S}$ ribosomal RNA gene. Abstr. Phytopathol. 82, 1083.

KIRKPATRICK, B.C., STRENGER, D.C., MORRIS, T.J., and PURCELL, A.H. (1987). Cloning and deletion of DNA from a nonculturable plant pathogenic mycoplasma-like organism. Science 238, 197 200.

KO, H.C., and LIN, C.P. (1994). Development and application of cloned DNA probes for a mycoplasma-like organism associated with sweet potato witches' broom. Phytopathology 84, 468-473.

KOLLAR, A., SEEMULLER, E., BONNET, F., SAILLARD, C., and BOVE, J.M. (1990). Isolation of the DNA of various plant pathogenic mycoplasma-like organisms from infected plants. Phytopathology 80, 233-237.

KUSKE, C.R., and KIRKPATRICK, B.C. (1992). Phylogenetic relationships between the western aster yellows mycoplasma-like organisms and other prokaryotes established by $16 \mathrm{~S}$ rRNA gene sequence. Int. J. Syst. Bacteriol. 42, 226-233.

LEE, I.-M., GUNDERSEN-RINDAL, D.E., and BERTACCINI, A. (1998). Phytoplasma: Ecology and genomic diversity. Phytopathology 88, 1359-1366.

LIM, P.-O., and SEARS, B.B. (1989). 16S rRNA sequence indicates that plant-pathogenic mycoplasma-like organisms are evolutionarily distinct from animal mycoplasmas. J. Bacteriol. 171, 5901-5906.

LINDAHL, L., and ZENGEL, J.M. (1986). Ribosomal genes in Escherichia coli. Annu. Rev. Genet. 20, 297-326.

LUDWIG, W., KIRCHHOF, G., KLUGBAUER, N., WEIZNEGGER, M., BETZL, D., EHRMANN, M., HERTEL, C., JILG, S., TAZEL, R., ZITZELBERGER, H., LIEBL, S., HOCHBERGER, M., SHAH, J., LANE, D., WALLNSFER, P.R., and SCHLEIFER, K.H. (1992). Complete 23S ribosomal RNA sequence of gram-positive bacteria with a low DNA G+C. Syst. Appl. Microbiol. 15, 477-500.

MENKE, M.A.O.H., LIESACK, W., and STACKEBRANDT, E. (1991). Ribotyping of 16S and 23S rRNA genes and organization of rrn: Operons in members of the bacterial genera Gemmata, Planctomyces, Thermotoga, Thermus and Verrucomicrobium. Arch. Microbiol. 155, 263-271.

NAKAGAWA, T., UEMORI, T., ASADA, K., KATO, I., and HARASAWA, R. (1992). Acholeplasma laidlawii has tRNA genes in the $16 \mathrm{~S}-23 \mathrm{~S}$ spacer of the rRNA operon. J. Bacteriol. 174, 81638165 .

OGASAWARA, N., MORIYA, S., and YOSHIKAWA, H. (1983). Structure and organization of rRNA operon in the region of replication origin of the Bacillus subtilis chromosome. Nucleic Acids Res. 11, 6301-6318.

PISABARRO, A., CORREIA, A., and MARTIN, J.F. (1998). Characterization of the $r r n B$ operon of the plant pathogen Rhodococcus fascians and targeted integrations of exogenous genes at rrn loci. Appl. Environ. Microbiol. 64, 1276-1282.

PONNAMBALAM, S., CHAN, B., and BUSBY, S. (1988). Functional analysis of different sequence elements in the Escherichia coli galactose operon P2 promoter. Mol. Microbiol. 2, 165-172.

RASMUSSEN, O.F., FRYDENBERG, J., and CHRISTIANSEN, C. (1987). Analysis of leader and spacer regions of the two rRNA operons of Mycoplasma PG50: Two tRNA genes are located upstream of rrnA. Mol. Gen. Genet. 208, 23-29.

RAZIN, S. (1985). Molecular biology and genetics of mycoplasmas (Mollicutes). Microbiol. Rev. 49, 419-455.

RAZIN, S., YOGEV, D., and NAOT, Y. (1998). Molecular biology and pathogenicity of mycoplasmas. Microbiol. Mol. Biol. Rev. 62, 1094-1156.

REE, H.K., CAO, K.M., THURLOW, D.L., and ZIMMERMANN, 
R.A. (1989). The structure and organization of the $16 \mathrm{~S}$ ribosomal RNA gene from the archaebacterium Thermoplasma acidophilum. Can. J. Microbiol. 35, 124-133.

REITER, W.-D., PALM, P., and ZILLING, W. (1988). Transcription termination in the archaebacterium Sulfolobus: Signal structures and linkage to transcription initiation. Nucleic Acids Res. 16, 2445-2459. ROGERS, M.J., SIMMONS, J., WALKER, R.T., WEISBURG, W.G., WOESE, C.R., TANNER, R.S., ROBINSON, I.M., STAHL, D.A., OLSEN, G., LEACH, R.H., and MANILOFF, J. (1985). Construction of the mycoplasma evolutionary tree from 5S rRNA sequence data. Proc. Natl. Acad. Sci. USA 82, 1160-1164.

SCHNEIDER, B., and SEEMULLER, E. (1994). Presence of two sets of ribosomal genes in phytopathogenic mollicutes. Appl. Environ. Microbiol. 60, 3409-3412.

SCHNEIDER, B., PADOVAN, A., De La RUE, S., EICHNER, R., DAVIS, R., BERNUETZ, A., and GIBB, K. (1999). Detection and differentiation of phytoplasmas in Australia: An update. Aust. J. Agricult. Res. 50, 333-342.

SEARS, B.B., and KIRKPATRICK, B.C. (1994). Unveiling the evolutionary relationships of plant-pathogenic mycoplasma-like organisms: Phylogenic insights may provide the key to culturing phytoplasmas. ASM-News 60, 307-312.

SMART, C.D., SCHNEIDER, B., BLOMQUIST, C.L., GUERRA, L.J., HARRISON, N.A., AHRENS, U., LORENZ, K.-H., SEEMULLER, E., and KIRKPATRICK, B.C. (1996). Phytoplasma-specific PCR primers based on sequence of the 16S-23S rRNA spacer region. Appl. Environ. Microbiol. 62, 2988-2993.

SRIVASTAVA, A.K., and SCHLESSINGER, D. (1990). Mechanism and regulation of bacterial ribosomal RNA processing. Annu. Rev. Microbiol. 44, 105-129.

TANAKA, R., ANDACHI, Y., and MUTO, A. (1991). Evolution of
tRNAs and tRNA genes in Acholeplasma laidlawii. Nucleic Acids Res. 19, 6787-6792.

TASCHKE, C., and HERRMANN, R. (1986). Analysis of transcription and processing signals of the 16S-23S rRNA operon of $M y$ coplasma hyopneumoniae. Mol. Gen. Genet. 205, 434-441.

TASCHKE, C., KLINKERT, M.-Q., WOLTERS, J., and HERRMANN, R. (1986). Organization of the ribosomal RNA genes in $M y$ coplasma hyopneumoniae. The 5S rRNA gene is separated from the $16 \mathrm{~S}$ and 23S rRNA genes. Mol. Gen. Genet. 205, 428-433.

TULLY, J.G. (1993). International Committee on Systemic Bacteriology Subcommittee on the Taxonomy of Mollicutes: Minutes of interim meeting, 1 and 2 August, 1992, Ames, Iowa. Int. J. Syst. Bacteriol. 43, 394-397.

WEISBERG, W.G., TULLY, J.G., ROSE, D.L., PETZEL, J.P., OYAIZU, H., YANG, D., MANDELCO, L., SECHREST, J., LAWRENCE, T.G., VAN ETTEN, J., MANILOFF, J., and WOESE, C.R. (1989). A phylogenetic analysis of the mycoplasmas: Basis for their classification. J. Bacteriol. 171, 6455-6467.

Address reprint requests to: Dr. Kuo-Chieh Ho Department of Botany National Taiwan University 1 Roosevelt Road, Sec. 4 Taipei 106, Taiwan

E-mail: kch@ccms.ntu.edu.tw

Received for publication July 17, 2000; received in revised form August 17, 2000; accepted October 25, 2000. 